\title{
Hydrochemical and Isotopic Characterization of the Waters of the Manglaralto River Basin (Ecuador) to Contribute to the Management of the Coastal Aquifer
}

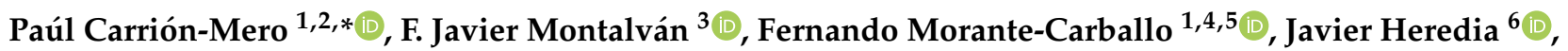 \\ F. Javier Elorza ${ }^{7}\left(\mathbb{D}\right.$, Joselyne Solórzano ${ }^{1,2, *}$ and Héctor Aguilera ${ }^{6}(\mathbb{D}$
}

1 Centro de Investigación y Proyectos Aplicados a las Ciencias de la Tierra (CIPAT), Campus Gustavo Galindo Km 30.5 Vía Perimetral, ESPOL Polytechnic University, Guayaquil P.O. Box 09-01-5863, Ecuador; fmorante@espol.edu.ec

2 Facultad de Ingeniería en Ciencias de la Tierra (FICT), Campus Gustavo Galindo Km 30.5 Vía Perimetral, ESPOL Polytechnic University, Guayaquil P.O. Box 09-01-5863, Ecuador

3 Centro de Investigación e Innovación de Geociencias (CIGEO), Facultad de Ciencias de la Ingeniería, Universidad Estatal Península de Santa Elena (UPSE), Avda. Principal La Libertad-Santa Elena, La Libertad 240204, Ecuador; fmontalvan@upse.edu.ec

4 Facultad de Ciencias Naturales y Matemáticas (FCNM), Campus Gustavo Galindo Km 30.5 Vía Perimetral, ESPOL Polytechnic University, Guayaquil P.O. Box 09-01-5863, Ecuador

5 Geo-Recursos y Aplicaciones GIGA, Campus Gustavo Galindo Km 30.5 Vía Perimetral, ESPOL Polytechnic University, Guayaquil P.O. Box 09-01-5863, Ecuador

6 Instituto Geológico y Minero de España. Ríos Rosas, 23, 28003 Madrid, Spain; j.heredia@igme.es (J.H.); h.aguilera@igme.es (H.A.)

check for updates

Citation: Carrión-Mero, P.; Montalván, FJ.; Morante-Carballo, F.; Heredia, J.; Elorza, F.J.; Solórzano, J.; Aguilera, H. Hydrochemical and Isotopic Characterization of the Waters of the Manglaralto River Basin (Ecuador) to Contribute to the Management of the Coastal Aquifer. Water 2021, 13, 537. https://doi.org/10.3390/w13040537

Academic Editor: Paolo Madonia

Received: 30 December 2020

Accepted: 12 February 2021

Published: 19 February 2021

Publisher's Note: MDPI stays neutral with regard to jurisdictional claims in published maps and institutional affiliations.

Copyright: (c) 2021 by the authors. Licensee MDPI, Basel, Switzerland. This article is an open access article distributed under the terms and conditions of the Creative Commons Attribution (CC BY) license (https:/ / creativecommons.org/licenses/by/ $4.0 /)$.
7 ETSI de Minas y Energía de Madrid, Universidad Politécnica de Madrid, 28003 Madrid, Spain; franciscojavier.elorza@upm.es

* Correspondence: pcarrion@espol.edu.ec (P.C.-M.); josbasol@espol.edu.ec (J.S.); Tel.: +593-99-826-5290 (P.C.-M.); +593-98-083-0953 (J.S.)

Abstract: Coastal aquifers are strategic and fundamental in the development of touristic areas. The coastal aquifer within the Manglaralto River Basin in Ecuador is essential, as it is the only source of water supply for a large part of the northern part of the Santa Elena province. It is a semi-arid region where high volumes of water are pumped from the aquifer, causing a significant drawdown of groundwater levels, thus affecting the water quality. This work aims to characterize the characteristics of groundwater in the coastal aquifer using hydrochemistry and stable isotopes to propose a hydrogeological conceptual model. The methodology for determining the chemical and isotopic characteristics of groundwater follows the following scheme: (i) studies of ionic concentrations using the Piper diagram, (ii) assessment of the origin of salinity through the $\mathrm{Cl} / \mathrm{Br}$ ratio, the presence of seawater intrusion through the Hydrochemical Facies Evolution Diagram HFE-D, (iii) characterization of precipitation events using stable isotopes $\left({ }^{18} \mathrm{O}\right.$ and $\left.{ }^{2} \mathrm{H}\right)$, and, (iv) development of a hydrogeological conceptual model of the study area. The results indicate that in the basin there are mixing processes of the existing water in the aquifer with recharge water, direct cation exchange processes in the freshening process during recharge, and evaporation in the unsaturated zone. A conceptual model of the flow system in the basin is built, based on the mentioned processes. The main conclusions are: seawater intrusion is present in the areas of the wells located closest to the coast, urban activity through septic tanks is affecting the quality of the aquifer, and rainfall is highly relevant in the different hydrochemical and isotopic processes that operate in the basin.

Keywords: Manglaralto coastal aquifer; seawater intrusion; freshening; hydrochemical; isotopes

\section{Introduction}

In the world and particularly in arid and semi-arid regions near the coast, groundwater is one of the primary sources of urban, agricultural, and industrial supply, consid- 
ering that $13 \%$ of the world population settles in these areas. They generally correspond to areas of touristic interest, which demand high volumes of water supply for inhabitants and visitors [1-4]. The nature of the coastal aquifers threatens groundwater sustainability, in some cases limiting the development in these areas if proper water management is not carried out [5].

High water demand from arid and semi-arid coastal aquifers leads to the overexploitation of the resource [5-7], causing a decrease in piezometric levels, mainly due to rainfall scarcity. In addition, increased groundwater pumping due to an increase in the population leads to seawater intrusion into the aquifer, influencing water quality. Precipitation infiltrating into the soil can cause the dissolution of evaporitic materials that may reach the aquifer, increasing ion concentration and affecting its quality [8]. The population needs assessments to collect precise information on available resources based on hydrogeological data [9]. Nevertheless, sometimes these hydrologic data are insufficient to understand the hydrodynamic behavior of groundwater flow. It is necessary to use different research methods such as hydrogeochemistry, stable isotopes, and ionic relationships, contributing to the definition and adjustment of conceptual hydrogeological models. In addition to hydrologic characterization, chemical and isotopic data on the water composition can help constrain the hydrology of these coastal areas.

Specifically, anthropogenic pollution of coastal aquifers caused by sewage water from septic tanks is on the rise. Due to the absence of treatment systems or inadequate maintenance of existing ones, wastewater infiltrates and reaches the groundwater, decreasing the quality of the water supply and harming certain agricultural activities $[10,11]$.

Aquifers are widely used for water supply and economic-social development, making the knowledge of the hydrogeological system, particularly groundwater source, recharge zones, and residence time, crucial for the correct water use and management. In the Calama aquifer in the Atacama Desert, Chile, hydrochemical and isotopic studies allowed us to propose a conceptual model of the hydrogeological system [12]. In the Todos Los Santos coastal aquifer in Baja California, Mexico, hydrochemical characterization detected marine intrusion [13]. Isotopic techniques were used to characterize groundwater, recharge zones, and zones of influence in the Ullum-Zonda and Tulum aquifers in San Juan, Argentina. Such techniques were used to determine climatic changes at different recharge times in the Botucatu aquifer in the Parana river basin, Brazil. In arid zones such as the Llamara salt flat, Chile, isotopic techniques characterize groundwater hydrological processes, evaporation problems, flow patterns, recharge, and discharge [14].

In the Santa Elena Peninsula (PSE), located on the central coast of Ecuador, there are two different water management contexts. To the south, where the urban area is located, water comes from the Guayas river basin through the Daule-Santa Elena diversion, while in the north, the source of water is exclusive to the coastal aquifers located in the sector [15]. The Manglaralto river basin is in the western foothills of the Chongón-Colonche mountain range. The aquifer is formed of Holocene alluvial deposits and rests discordantly on rocks of ages ranging from the Upper Cretaceous to the Lower Miocene. The Cayo formation forms the bottom-top stratigraphic sequence; it is $1700 \mathrm{~m}$ thick, has marine volcano-clastic rocks and a sedimentary sequence that emerges in the upper basin. The Guayaquil formation is $370 \mathrm{~m}$ thick, overlays the Cayo formation, and is constituted by chert shales [16-18]. A shallow marine environment with limestone contributions resulting from marine transgressions and regressions follows. These calcareous stratigraphic sequences are the Upper member of the San Eduardo formation. (Javita member) of the Middle Eocene; they were formed by calcareous flysch [16], in which coarse-grained calcarenites distinguished in alternation with microbreaks and microconglomerates with a predominance of fossilized algae fragments, with macro contents foraminifera of the Eocene and discocycline lepidocycline genus, pelecypod mollusks, bivalve remnant spicules, echinoderm spicules, and bryozoan spines. The Socorro formation overlays this formation (Middle and Upper Eocene), followed by the Seca formation (Upper Eocene). These two layers are part of the Ancón group and have calcareous characteristics. Following this, is the Zapotal and 
the Dos Bocas member (Lower Miocene) belonging to the Tosagua formation Chloride in the aquifer is due to the mixture of water that infiltrates from rainfall with connate seawater [19]. The recharge of these aquifers depends exclusively on rainfall. The absence of it, along with the increase in local and varying populations, hinders groundwater levels' recovery over time. In the Manglaralto aquifer, there are 12 pumping wells, managed by the Manglaralto Regional Drinking Water Management Board (JAAPMAN) [20], supplying the Montañita, Manglaralto, Río Chico, Cadeate, San Antonio, and Libertador Bolívar communities [21], reaching approximately 30,000 inhabitants. The economy in this part of the coast is based on fishing, tourism, and gastronomy, but the floating population during the beach season (January to May) can triple the water demand, causing the aquifer to be overexploited [22,23]. In this sector, only $34.15 \%$ of the population is economically active (INEC, 2010) [24]. Wastewater treatment in the study area is carried out by sewage and oxidation ponds located in the Montañita community. In some cases, it does not cover the entire population, mainly in the peripheries, which leads to the construction of septic tanks that are not hermetic, allowing wastewater to escape and infiltrate into the ground [25]. In the Manglaralto basin, of approximately $52 \mathrm{~km}^{2}$, the unconfined aquifer shows phreatic levels ranging from 1.72 m.a.s.l. (meters above sea level) in the wells closest to the sea to 23.1 m.a.s.l. in the wells located inland in the lower basin. This aquifer develops in the alluvial terraces over approximately $6 \mathrm{~km}^{2}$, consisting mainly of gravels, sands, silts, and clays, through which groundwater flows. It is used in higher volume for supply by $92.67 \%$ of the inhabitants, $2.26 \%$ from surface water sources, $2.26 \%$ from surface water sources, $2.26 \%$ from rainwater, and 3.34\% from tankers [26]. Different factors such as population growth, new housing projects in the area, seawater intrusion into the aquifer, long periods of pumping, and the La Niña and El Niño phenomena have led inhabitants to implement resilience strategies for aquifer recovery, such as the application of ancestral knowledge by building a dyke-"tape" (ancestral word in Spanish that means dyke) in the Manglaralto riverbed to increase recharge artificially $[27,28]$. The particular characteristics of this aquifer are considered a natural laboratory where different studies are carried out. Due to the residents' resilient actions for sustainability, the area was named geosite as part of the Geopark Santa Elena project [23,27].

In the Chongón-Colonche mountain range area where the upper basin of the Manglaralto River is located, at approximately 660 m.a.s.l., precipitation occurs that forms surface runoff and water infiltrates through cracks or fractures until it reaches alluvial materials. In the middle and lower areas of the basin, infiltrating rainfall water flows directly through these materials. The thickness of the terraces in the upper and lower basin reaches 1 and $30 \mathrm{~m}$, respectively. The extraction wells are drilled in the lower basin, where the best hydraulic conditions are found (Figure 1, [19]).

The hydrogeological characteristics of the aquifer were investigated in previous works, where an initial conceptual model was defined (Figure 2, [19]), and in research projects carried out by the academy. Porosity ranges between 0.2 and 0.3 , permeability ranges between 1.6 and $5 \mathrm{~m} /$ day, and the storage coefficient is 0.002 . These values were determined within the projects ECU/8/026: Characterization of Coastal Aquifers in the Santa Elena Peninsula and RLA/8/041: Characterization of Coastal Aquifers in the Santa Elena Peninsula, funded by the International Atomic Energy Agency (IAEA) [29,30].

Is it possible to get to know, through hydrochemical data and isotopic information, how seawater intrusion, water quality, and type of water affect coastal aquifers management?

The work aims to characterize the waters circulating in the Manglaralto hydrogeological system, through hydrochemical and isotopic techniques, to determine the types of groundwater, the presence of seawater intrusion, and the direction of flow. With this information, a conceptual hydrogeological model is proposed to support decision-making according to the aquifer's correct management in terms of its quality for human consumption. 


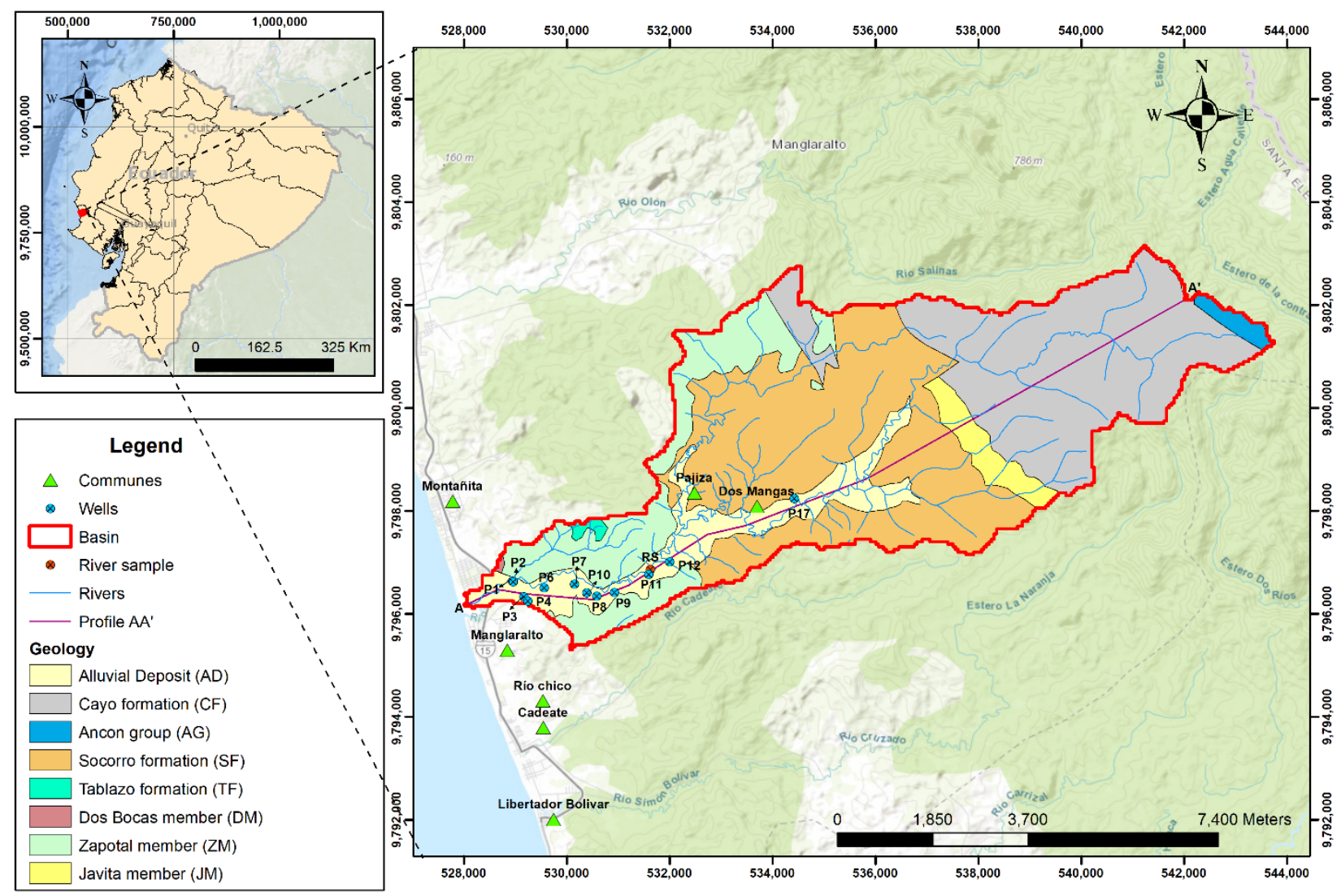

Figure 1. Map of the Manglaralto river basin, geology, location of wells, and river sample.

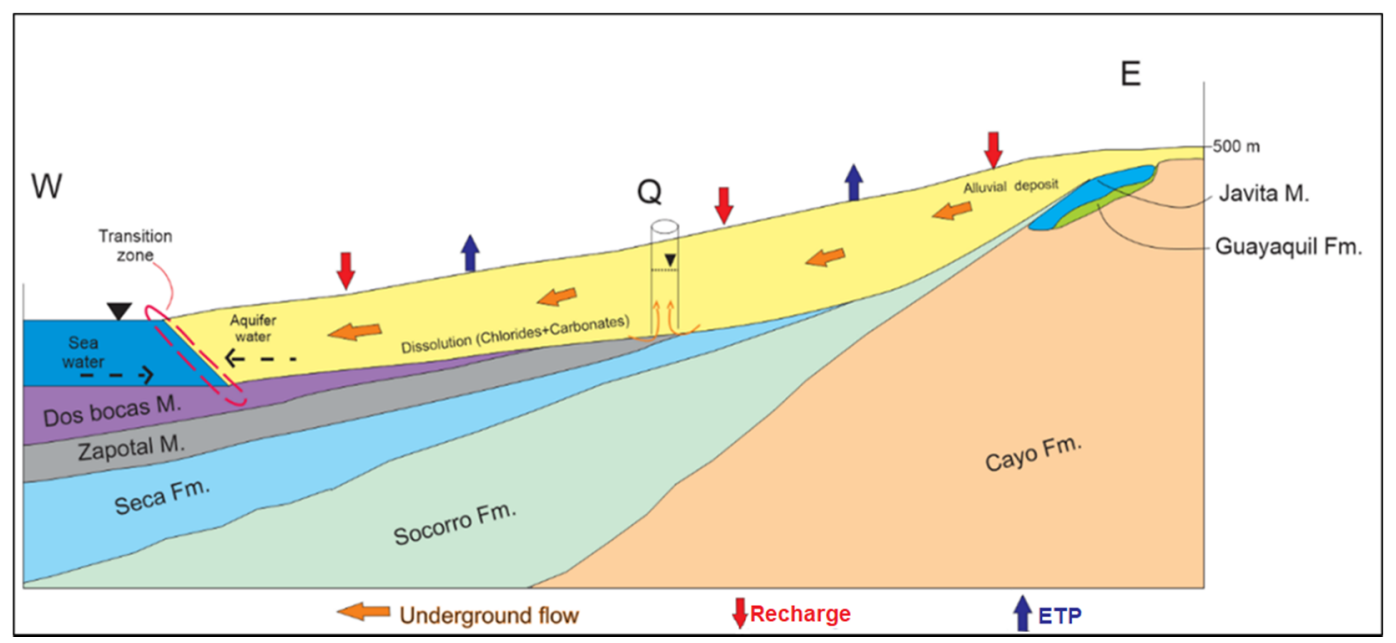

Figure 2. Conceptual model of the hydrogeological system of the Manglaralto river basin [19].

\section{Materials and Methods}

The general methodology considers three stages. The characterization consisted of hydrochemical, $\mathrm{Cl} / \mathrm{Br}$ and isotopic techniques.

\subsection{Fieldwork and Laboratory Analysis}

The hydrochemical characterization of the Manglaralto aquifer comprised data obtained from eight wells in two sampling campaigns, August 2018 (dry season) and December 2018 (rainy season). The data obtained in situ were $\mathrm{pH}$ (potential hydrogen), 
temperature (T), Electrical Conductivity (EC), and Total dissolved solids (TDS). The Gruentec laboratory carried out chemical analyzes (Table 1).

Table 1. Hydrochemical data of groundwater in the Manglaralto river basin from August 2018 and December 2018. Temperature, $\mathrm{T}\left({ }^{\circ} \mathrm{C}\right)$, anions and cations $(\mathrm{mg} / \mathrm{L})$ and $(\mathrm{mmol} / \mathrm{L}), \mathrm{EC}(\mu \mathrm{S} / \mathrm{cm}), \mathrm{TDS}(\mathrm{mg} / \mathrm{L})$.

\begin{tabular}{|c|c|c|c|c|c|c|c|c|c|c|c|c|}
\hline \multirow{3}{*}{ Well/Campaign } & \multirow{3}{*}{$\mathrm{pH}$} & $\mathbf{T}$ & EC & $\mathrm{Na}^{+}$ & $\mathrm{K}^{+}$ & $\mathrm{Ca}^{2+}$ & $\mathrm{Mg}^{2+}$ & $\mathrm{Cl}^{-}$ & $\mathrm{Br}^{-}$ & $\mathrm{SO}_{4}{ }^{2-}$ & $\mathrm{HCO}_{3}^{-}$ & TSD \\
\hline & & \multirow{2}{*}{${ }^{\circ} \mathrm{C}$} & \multirow{2}{*}{$\mu \mathrm{S} / \mathrm{cm}$} & $\mathrm{mg} / \mathrm{L}$ & $\mathrm{mg} / \mathrm{L}$ & $\mathrm{mg} / \mathrm{L}$ & $\mathrm{mg} / \mathrm{L}$ & $\mathrm{mg} / \mathrm{L}$ & $\mathrm{mg} / \mathrm{L}$ & $\mathrm{mg} / \mathrm{L}$ & $\mathrm{mg} / \mathrm{L}$ & \multirow{2}{*}{$\mathrm{mg} / \mathrm{L}$} \\
\hline & & & & $\mathrm{mmol} / \mathrm{L}$ & $\mathrm{mmol} / \mathrm{L}$ & $\mathrm{mmol} / \mathrm{L}$ & $\mathrm{mmol} / \mathrm{L}$ & $\mathrm{mmol} / \mathrm{L}$ & $\mathrm{mmol} / \mathrm{L}$ & $\mathrm{mmol} / \mathrm{L}$ & $\mathrm{mmol} / \mathrm{L}$ & \\
\hline \multirow{2}{*}{ P2/August } & \multirow{2}{*}{7.1} & \multirow{2}{*}{26.5} & \multirow{2}{*}{7080} & 274 & 18 & 588 & 110 & 1224 & 5.1 & 272 & 303 & \multirow{2}{*}{2869} \\
\hline & & & & 11.97 & 0.46 & 14.70 & 4.53 & 34.48 & 0.06 & 2.83 & 4.97 & \\
\hline \multirow{2}{*}{ P3/August } & \multirow[b]{2}{*}{7.2} & \multirow[b]{2}{*}{26.9} & \multirow{2}{*}{3240} & 187 & 12 & 239 & 46 & 370 & 2.1 & 176 & 309 & \multirow{2}{*}{1242} \\
\hline & & & & 8.17 & 0.31 & 5.98 & 1.89 & 10.42 & 0.03 & 1.83 & 5.07 & \\
\hline \multirow{2}{*}{ P4/August } & \multirow{2}{*}{7.7} & \multirow{2}{*}{26} & \multirow{2}{*}{5370} & 317 & 14 & 346 & 73 & 723 & 3.8 & 394 & 383 & \multirow{2}{*}{2116} \\
\hline & & & & 13.84 & 0.36 & 8.65 & 3.00 & 20.37 & 0.05 & 4.10 & 6.28 & \\
\hline \multirow{2}{*}{ P6/August } & \multirow{2}{*}{7.5} & \multirow{2}{*}{26.1} & \multirow{2}{*}{1757} & 126 & 8.1 & 96 & 18 & 90 & 0.42 & 178 & 327 & \multirow{2}{*}{696} \\
\hline & & & & 5.50 & 0.21 & 2.40 & 0.74 & 2.54 & 0.01 & 1.85 & 5.36 & \\
\hline P9/Auoust & 75 & & 1729 & 133 & 6.5 & 87 & 22 & 111 & 0.5 & 176 & 391 & \\
\hline 19/ August & 1.5 & 24.6 & $1 / 29$ & 5.81 & 0.17 & 2.18 & 0.91 & 3.13 & 0.01 & 1.83 & 6.41 & $1 / 15$ \\
\hline P10/A11oust & & & & 110 & 6.4 & 76 & 16 & 108 & 0.57 & 137 & 323 & \\
\hline $110 /$ August & 7.2 & 24.5 & 1700 & 4.80 & 0.16 & 1.90 & 0.66 & 3.04 & 0.01 & 1.43 & 5.30 & 646 \\
\hline & & & & 74 & 7.4 & 87 & 15 & 86 & 0.4 & 121 & 303 & \\
\hline P11/August & 7.2 & 26 & 1512 & 3.23 & 0.19 & 2.18 & 0.62 & 2.42 & 0.01 & 1.26 & 4.97 & 572 \\
\hline & & & & 93 & 8.2 & 90 & 20 & 101 & 0.44 & 149 & 330 & \\
\hline P12/August & 7.5 & 25.2 & 1731 & 4.06 & 0.21 & 2.25 & 0.82 & 2.85 & 0.01 & 1.55 & 5.41 & 613 \\
\hline & & & & 173 & 11 & 294 & 55 & 487 & 1.6 & 170 & 293 & \\
\hline P2/December & 7.3 & 27.3 & 2370 & 7.55 & 0.28 & 7.35 & 2.26 & 13.72 & 0.02 & 1.77 & 4.80 & 1867 \\
\hline & & & & 141 & 5.4 & 62 & 16 & 80 & 0.34 & 118 & 280 & \\
\hline P3/December & 7.5 & 26.7 & 961 & 8.17 & 0.31 & 5.98 & 1.89 & 10.42 & 0.03 & 1.83 & 5.07 & 595 \\
\hline & & & & 216 & 8.6 & 167 & 35 & 281 & 1.1 & 240 & 340 & \\
\hline P4/December & 7.2 & 26.4 & 1923 & 9.43 & 0.22 & 4.18 & 1.44 & 7.92 & 0.01 & 2.50 & 5.57 & 1203 \\
\hline & & & & 96 & 6 & 73 & 14 & 70 & 0.19 & 138 & 293 & \\
\hline Pb/December & 7.2 & 25.6 & 941 & 4.19 & 0.15 & 1.83 & 0.58 & 1.97 & 0.00 & 1.44 & 4.80 & 598 \\
\hline & & & & 151 & 5.7 & 85 & 26 & 103 & 0.31 & 166 & 389 & 794 \\
\hline Py/December & 7.3 & 26 & 1296 & 6.59 & 0.15 & 2.13 & 1.07 & 2.90 & 0.00 & 1.73 & 6.38 & 794 \\
\hline P10/December & & 264 & & 127 & 5.4 & 70 & 14 & 82 & 0.32 & 123 & 327 & \\
\hline $110 / 1$ & 7.4 & 20.4 & 1036 & 5.55 & 0.14 & 1.75 & 0.58 & 2.31 & 0.00 & 1.28 & 5.36 & 653 \\
\hline & & & & 75 & 6.5 & 78 & 14 & 71 & 0.25 & 104 & 269 & \\
\hline P11/D & 7.4 & 25.9 & 870 & 3.28 & 0.17 & 1.95 & 0.58 & 2.00 & 0.00 & 1.08 & 4.41 & 541 \\
\hline & & & & 84 & 6.4 & 67 & 16 & 78 & 0.27 & 108 & 277 & \\
\hline P12/December & 7.8 & 24.4 & 927 & 3.67 & 0.16 & 1.68 & 0.66 & 2.20 & 0.00 & 1.13 & 4.54 & 574 \\
\hline
\end{tabular}

The 16 samples were preserved at a constant temperature of $4{ }^{\circ} \mathrm{C}$ and subsequently transported to the laboratories. Surfactants and hexavalent chromium were preserved with sodium hydroxide and the metal ions with nitric acid. The Hach multiparameter (Elec 78 probe) was used to measure $\mathrm{pH}$ and temperature, and the WTW multiparameter (Elec 06 probe) was used for electrical conductivity determination.

The concentrations of calcium, magnesium, potassium, sodium, and bromide were determined by inductively coupled plasma spectrometry coupled with a mass spectrometer (ICP-MS), chloride and sulfate were determined through high-pressure liquid chromatography (HPLC) and carbonate and bicarbonate were determined through volumetric titration. 


\subsection{Hydrochemistry}

The Piper diagram (1953) [31] was used for hydrochemical characterization of the hydrogeological system. It plots the concentration of major ions water percentages in a triangular diagram, in which each point corresponds to a sample. The program EasyQuim 5.0 was used to build the Piper diagram [31]. The chloride/bromide ratio [32] suggests the origin of salinity and aquifer contamination due to the concentration of $\mathrm{Cl}^{-}$ and $\mathrm{Br}^{-}$, in which the first occurs only by rainfall and, in contrast, the second occurs by marine-coastal environments. The Hydrochemical Facies Evolution Diagram (HFE-D) is a rectangular diagram that allows analyzing the interaction of aquifer water with seawater and its dynamics through the concentrations of the major anions $\left(\mathrm{Cl}^{-}, \mathrm{HCO}^{3-}\right.$ and $\left.\mathrm{SO}_{4}{ }^{2-}\right)$ and cations $\left(\mathrm{Na}^{+}\right.$and $\left.\mathrm{Ca}^{2+}\right)$ expressed as a percentage [33-37]. Concentration curves by seawater and dilution curves by infiltration of rainwater were used to determine theoretical processes of concentration and dilution, respectively [36-38].

\subsection{Isotopes}

This work used isotope data from a previous study (Table 2, [39]). The World Meteoric Line, GMWL [39], and the Local Meteoric Line, LMWL [39], contributed to the ${ }^{18} \mathrm{O}$ and ${ }^{2} \mathrm{H}$ data's reinterpretation of the characterization of residence time and circulation dynamics.

Table 2. Compilation of Table $1{ }^{18} \mathrm{O}$ and ${ }^{2} \mathrm{H}$ isotope data from the waters of the Manglaralto hydrogeological system obtained in campaigns from 2012 to 2014 [39].

\begin{tabular}{ccccccccc}
\hline \multirow{2}{*}{ Well } & \multicolumn{2}{c}{$\mathbf{2 0 1 4}-$ April } & \multicolumn{2}{c}{$\mathbf{2 0 1 3}-$ November } & \multicolumn{2}{c}{$\mathbf{2 0 1 2 - N o v e m b e r}$} & \multicolumn{2}{c}{ 2012-January } \\
& ${ }^{\mathbf{1 8}} \mathbf{O}$ & ${ }^{\mathbf{2}} \mathbf{H}$ & ${ }^{\mathbf{1 8}} \mathbf{O}$ & ${ }^{\mathbf{2}} \mathbf{H}$ & ${ }^{\mathbf{1 8}} \mathbf{O}$ & ${ }^{\mathbf{2}} \mathbf{H}$ & ${ }^{\mathbf{1 8}} \mathbf{O}$ & ${ }^{\mathbf{2}} \mathbf{H}$ \\
\hline P2 & -2.06 & -8.8 & -2.30 & -8.5 & -2.20 & -7.6 & -2.01 & -7.5 \\
P3 & -2.37 & -8.7 & -2.51 & -9.9 & -2.22 & -7.8 & -2.15 & -8.3 \\
P4 & - & - & - & - & -2.26 & -7.6 & -2.05 & -7.4 \\
P6 & -2.41 & -9.0 & -2.27 & -8.3 & -2.10 & -7.4 & -1.84 & -8.8 \\
P7 & - & - & - & - & -2.32 & -10.2 & -1.99 & -9.6 \\
P8 & -2.37 & -8.6 & -2.42 & -9.0 & -2.23 & -8.7 & -1.73 & -8.6 \\
P12 & & & -2.38 & -8.9 & - & - & - & - \\
P17 & -2.53 & -10.5 & -2.65 & -8.4 & - & - & - & - \\
River & - & - & -2.32 & -8.7 & - & - & - & - \\
\hline
\end{tabular}

\section{Results}

\subsection{Hydrochemistry}

The water samples (Table 1), characterized by the Piper diagram (Figure 3), indicate two water families in the underground flow system. The first family of waters corresponds to the wells further into the aquifer, presenting mainly calcium-sodium bicarbonate facies with $\mathrm{CE}$ between 900 to $1700 \mu \mathrm{S} / \mathrm{cm}$. The diagram shows that in the first campaign in August 2018, wells P6, P9, P10, P11 and P12 present concentrations between 4.97 and $6.41 \mathrm{mmol} / \mathrm{L}$ of $\mathrm{HCO}_{3}$, between 3.41 and $5.95 \mathrm{mmol} / \mathrm{L}$ of $\mathrm{Na}+\mathrm{K}$, and between 1.90 and $2.40 \mathrm{mmol} / \mathrm{L}$ of $\mathrm{Ca}^{2+}$. In the second campaign (December 2018), the concentrations were between 4.41 and $6.38 \mathrm{mmol} / \mathrm{L}$ of $\mathrm{CO}_{3}+\mathrm{HCO}_{3}$, between 3.43 and $6.71 \mathrm{mmol} / \mathrm{L}$ of $\mathrm{Na}$ $+\mathrm{K}$, and between 1.68 and $2,13 \mathrm{mmol} / \mathrm{L}$ of $\mathrm{Ca}^{2+}$. The second family corresponds to the wells closest to the sea, which have the highest EC between 5300 to $7000 \mu \mathrm{S} / \mathrm{cm}$, presenting various facies, depending on the time of year. In the August 2018 campaign, wells P2, P3 and P4 present concentrations of 34.48 and $14.70 \mathrm{mmol} / \mathrm{L}, 10.42$ and $8.98 \mathrm{mmol} / \mathrm{L}$ and 20.37 and $8.65 \mathrm{mmol} / \mathrm{L} \mathrm{Cl}^{-}$and $\mathrm{Ca}^{2+}$ respectively. In the December 2018 campaign, well P2

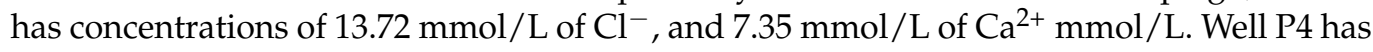
$7.92 \mathrm{mmol} / \mathrm{L}$ of $\mathrm{Cl}^{-}$and $9.43 \mathrm{mmol} / \mathrm{L}$ of $\mathrm{Na}^{+}$. Well P3 has concentrations of $5.07 \mathrm{mmol} / \mathrm{L}$ of $\mathrm{HCO}_{3}$ and $8.17 \mathrm{mmol} / \mathrm{L}$ of $\mathrm{Na}^{+}$. 


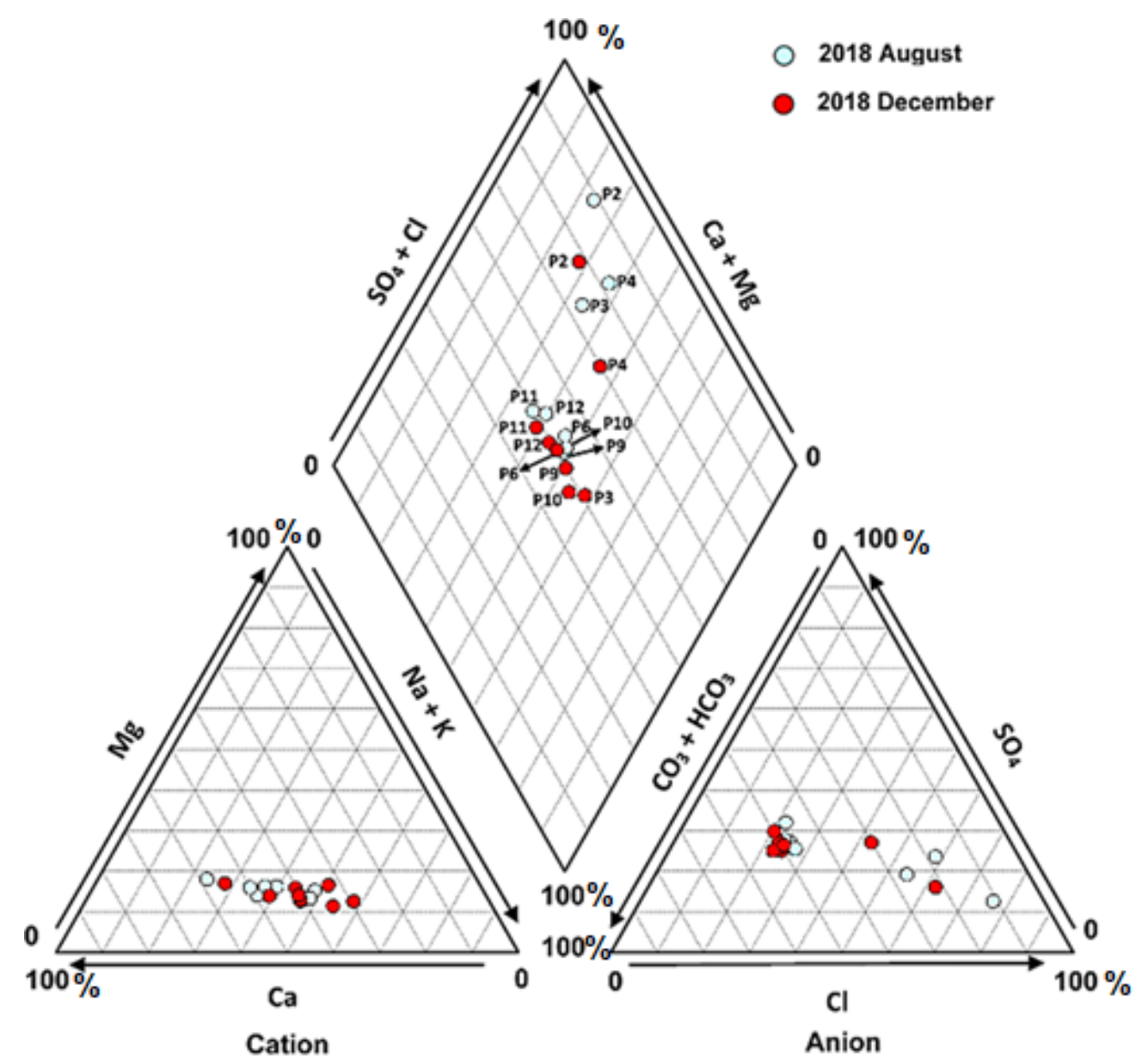

Figure 3. Piper diagram showing the hydrochemical characteristics of the Manglaralto aquifer groundwater samples of the campaigns in August 2018 and December 2018.

The physical-chemical processes of dilution, evaporation, and mixing can affect $\mathrm{Cl}$ and Br ions by varying their absolute concentration but not the ratio $\mathrm{Cl}^{-} / \mathrm{Br}^{-}$. The $\mathrm{Cl} / \mathrm{Br}$ ratios in the dry season and the rainy season range between 420 to 540 and 530 to 830 , respectively. There are differences between the wells closest to the coast and inland wells regarding $\mathrm{Cl}$ ions' concentration, with concentrated values ranging from 370 to $1200 \mathrm{mg} / \mathrm{L}$ for the former and lower values between 80 and $110 \mathrm{mg} / \mathrm{L}$ for the latter. In the December 2018 campaign, the wells further into the basin were close to rainfall recharge waters, while the increase in $\mathrm{Cl}^{-}$in the August 2018 campaign moved these wells slightly away from this group (Figure 4). Wells close to the sea (P2, P3, and P4) show large differences between the two campaigns. In the dry season, there is a predominance of flow from the sea to the aquifer, which has a greater incidence of anthropogenic activity, due to the influence of the urban area by sewage outlets, shown in Figure 4 as regards wells P2, P3, and P4. In the rainy season, there is a predominance of flow from the aquifer to the sea, a dilution factor occurring, strengthened by the artificial recharge caused using "tapes" or dams.

The seawater intrusion analysis carried out through the Hydrochemical Facies Evolution Diagram (HFE-D) shows marked differences between both campaigns, mainly in the wells near the sea (Figure 5, Table 3). The analyses showed an electroneutrality between 1 and $11 \%$, a typical range for water analysis. The August 2018 campaign shows that five wells far from the sea (P6, P9, P10, P11, and P12) correspond to the sub-state called $\mathrm{f}_{3}$ according to the evolved groundwater classification, generally considering freshwater with -MixHCO3 facies and different cation percentages. Those samples show two groups, the first (P6, P9, and P10) with -MixNa facies, and the second (P11 and P12) with -MixCa facies. The remaining wells close to the sea are in a state $i_{3}$ (seawater intrusion), presenting 
$\mathrm{Cl}^{-}$facies with percentages of -MixCa in two of these wells (P3 and P4) and high $\mathrm{Ca}^{2+}$ in well P2.

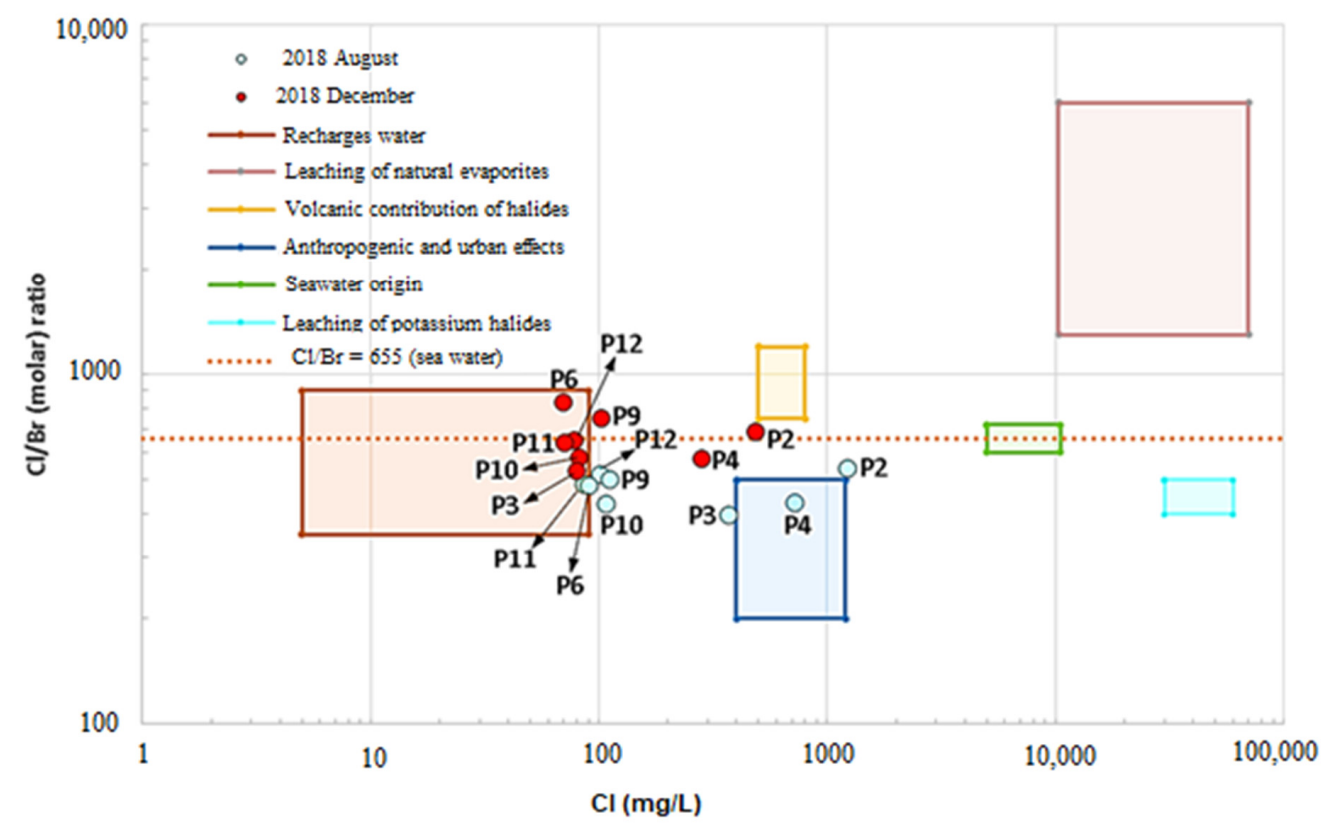

Figure 4. $\mathrm{Cl} / \mathrm{Br}$ ratio of the groundwater samples of the Manglaralto river basin in August 2018 and December 2018.

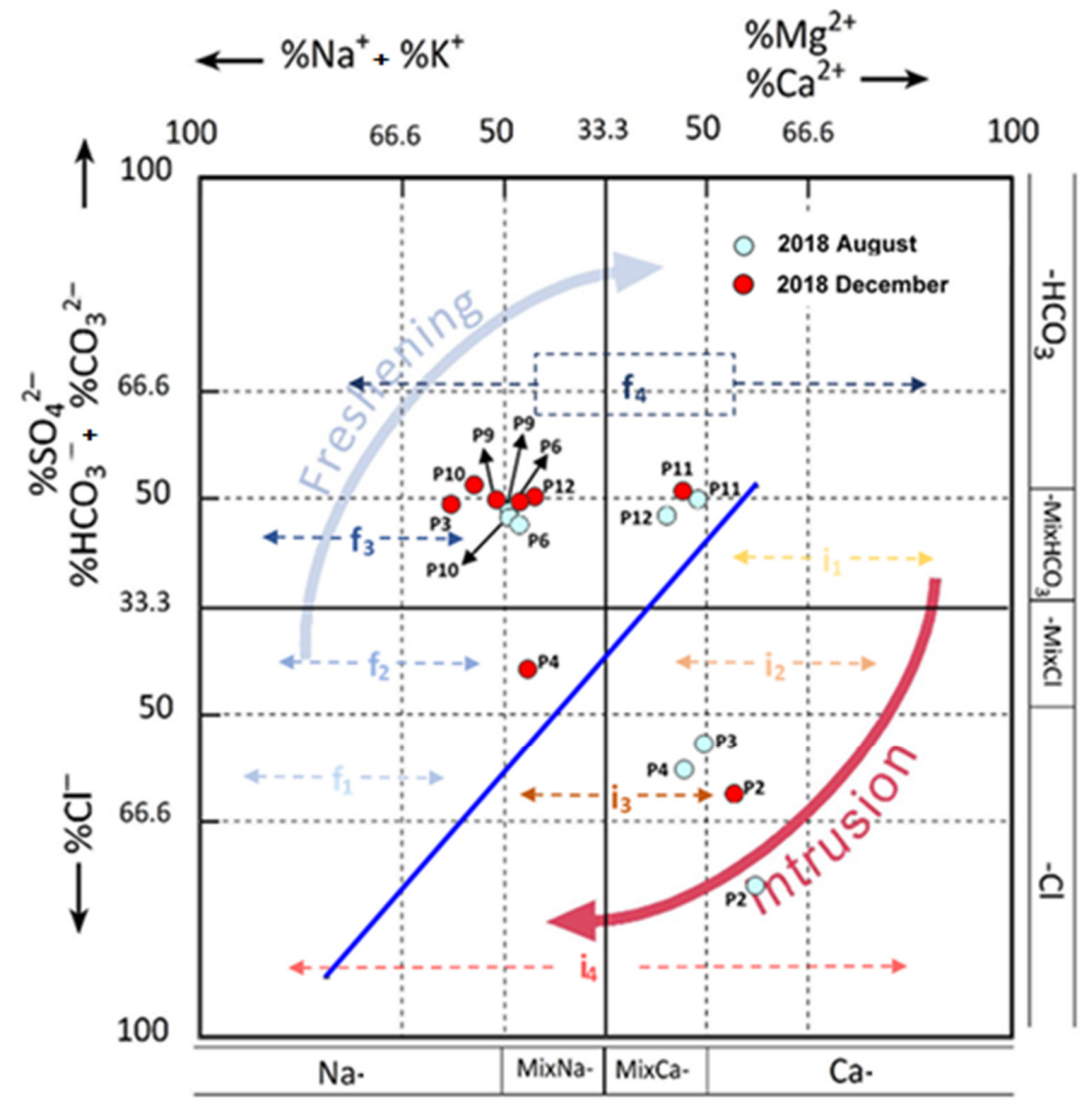

Figure 5. Characterization of the groundwater of the Manglaralto river basin using the Hydrochemical Facies Evolution Diagram (HFE-D) showing the sub-states of seawater intrusion (i) and freshwater freshening (f). 
Table 3. Summary of the sub-state, phase, and ionic evolution of the groundwater of the Manglaralto river basin between August 2018 and December 2018.

\begin{tabular}{|c|c|c|c|c|c|c|}
\hline \multirow[b]{2}{*}{ Well } & \multicolumn{3}{|c|}{ August 2018} & \multicolumn{3}{|c|}{ December 2018} \\
\hline & Sub-State & Phase & Ionic Facies & Sub-State & Phase & Ionic Facies \\
\hline P2 & $\mathrm{i}_{4}$ & Seawater intrusion & $\mathrm{Ca}-\mathrm{Cl}$ & $i_{3}$ & Seawater intrusion & $\mathrm{Ca}-\mathrm{Cl}$ \\
\hline P3 & $\mathrm{i}_{3}$ & Seawater intrusion & $\mathrm{MixCa}-\mathrm{Cl}$ & $\mathrm{f}_{3}$ & Freshwater & $\mathrm{MixHCO}_{3}-\mathrm{Na}$ \\
\hline P4 & $i_{3}$ & Seawater intrusion & $\mathrm{MixCa}-\mathrm{Cl}$ & $\mathrm{f}_{2}$ & Freshwater & MixCl-MixNa \\
\hline P6 & $\mathrm{f}_{3}$ & Freshwater & $\mathrm{MixHCO}_{3}-\mathrm{MixNa}$ & $\mathrm{f}_{3}$ & Freshwater & $\mathrm{MixHCO}_{3}-\mathrm{MixNa}$ \\
\hline P9 & $\mathrm{f}_{3}$ & Freshwater & $\mathrm{MixHCO}_{3}-\mathrm{MixNa}$ & $\mathrm{f}_{3}$ & Freshwater & $\mathrm{HCO}_{3}-\mathrm{Na}$ \\
\hline P10 & $\mathrm{f}_{3}$ & Freshwater & $\mathrm{MixHCO}-\mathrm{MixNa}$ & $\mathrm{f}_{4}$ & Freshwater & $\mathrm{HCO}_{3}-\mathrm{Na}$ \\
\hline P11 & $\mathrm{f}_{3}$ & Freshwater & $\mathrm{HCO}_{3}-\mathrm{MixCa}$ & $\mathrm{f}_{4}$ & Freshwater & $\mathrm{HCO}_{3}-\mathrm{MixCa}$ \\
\hline P12 & $\mathrm{f}_{3}$ & Freshwater & $\mathrm{MixHCO}_{3}-\mathrm{MixCa}$ & $\mathrm{f}_{4}$ & Freshwater & $\mathrm{HCO}_{3}-\mathrm{MixNa}$ \\
\hline
\end{tabular}

In the December 2018 campaign, the wells within the basin show an evolution from sub-state $\mathrm{f}_{3}\left(-\mathrm{MixHCO}_{3}\right)$ to sub-state $\mathrm{f}_{4}\left(-\mathrm{HCO}_{3}\right.$ freshwater facies). In wells P6, P9 and P10, there is a slight increase in the Na cation, while in wells P11 and P12, there is an increase in the concentration of carbonates. In P11, the $\mathrm{Ca}^{+}$concentration decreases, and $\mathrm{P} 12$ evolves from calcium to sodium. The wells near the sea show a particular evolution; in P4, chloride decreases from a sub-state $\mathrm{i}_{3}(-\mathrm{Cl})$ to a sub-state $\mathrm{f}_{2}(-\mathrm{MixCl})$, evolving from -MixCa to -MixNa. In well P3, there is a considerable evolution in ions, going from sub-state $\mathrm{i}_{3}(-\mathrm{Cl})$ to sub-state $\mathrm{f}_{3}\left(-\mathrm{MixHCO}_{3}\right)$ and from calcium to sodium. Finally, P2 maintains calcium chloride facies.

The HFE-D graph (Figure 5) shows moderate cation exchange processes in the aquifer. Wells P3 and P4 are located further from the riverbed, where the presence of clayey stratifications affects the Ca-Na cation exchange. On the other hand, wells very close to the riverbed, which do not contain clay material, follow the pattern of not reflecting any cation exchange process, except for well $\mathrm{P} 12$, which produces a slight cation exchange, according to Gimenez-Forcada [33-35]. Because there are no clays in the riverbed while moving away from the riverbed, there are clayey stratifications that affect the exchange.

The sub-state where the freshwater zone " $\mathrm{f}_{1}$ " evolves corresponds to MixNa-Cl, " $\mathrm{f}_{2}$ " to MixNa-MixCl, " $\mathrm{f}_{3}$ " to $\left(\mathrm{MixCa}-\mathrm{MixHCO}{ }_{3}, \mathrm{Ca}-\mathrm{MixHCO}_{3}\right)$ and " $\mathrm{f}_{4}$ " to $\mathrm{Ca}-\mathrm{HCO}_{3}$, where $\% \mathrm{Ca}$ $<$ 66.6. The area where seawater intrusion evolves is " $\mathrm{i}_{1}$ " to Ca-MixHCO ${ }_{3}, " \mathrm{i}_{2}$ " to (MixCa$\mathrm{MixCl}, \mathrm{Ca}-\mathrm{MixCl})$, "i $\mathrm{i}_{3}$ " to (MixNa-Cl $(50<\% \mathrm{Cl}<66.6)$, MixCa-Cl, Ca-Cl) and " $\mathrm{i}_{4}$ " to MixNa-Cl, where $\% \mathrm{Cl}>66.6)$. The blue line is the succession of facies along the line of mixing [34].

The Piper and HFE-D diagrams indicate that there are two types of water, chlorinated and carbonated. The wells near the sea have calcium chloride water in the dry season. In the wet season, due to the influence of rainfall and the effects of artificial recharge by the dyke, well P4 changes its composition to sodium chloride and well P3 to carbonate sodium. The well P2 keeps a calcium chloride composition but with a decreased $\mathrm{Cl}^{-}$concentration. Wells P11 and P12 show calcium bicarbonate water in the dry season, whereas the chemical composition in the remaining inland wells is sodium bicarbonate. Due to the infiltration of rainfall during the wet season, all the inland wells present sodium bicarbonate composition, except for well P11, which maintains its initial chemical composition (Figure 1, Figure 3, and Figure 5).

The concentration of the aquifer water is determined using the fraction of sea water (fsw), which is calculated as [37-39]:

$$
\mathrm{f}_{\mathrm{sw}}=\frac{\mathrm{C}_{\mathrm{Cl}} \text { sample }-\mathrm{C}_{\mathrm{Cl}, \mathrm{fwmin}}}{\mathrm{C}_{\mathrm{Cl}, \mathrm{Sw}}-\mathrm{C}_{\mathrm{Cl}, \mathrm{fw}}}
$$

where, $\mathrm{C}_{\mathrm{Cl} \text {,sample, }}$ is the $\mathrm{Cl}$ concentration in the sample; $\mathrm{C}_{\mathrm{Cl} \text {,fwmin }}$ is the lowest $\mathrm{Cl}$ concentration in aquifer water, and $\mathrm{C}_{\mathrm{Cl}}, \mathrm{Sw}$ is the $\mathrm{Cl}$ concentration in seawater. 
Theoretical concentration curves for seawater $\left(\mathrm{C}_{\mathrm{i}, \mathrm{fw}-\mathrm{sw}}\right)$ are determined through the following expression:

$$
\mathrm{C}_{\mathrm{i}, \mathrm{fw}-\mathrm{sw}}=\mathrm{fsw} \times \mathrm{C}_{\mathrm{i}, \mathrm{sw}}+(1-\mathrm{fsw}) \times \mathrm{C}_{\mathrm{i}, \mathrm{fwmin}}
$$

To determine the dilution of the aquifer waters by rainwater, the following expression is used [37]:

$$
\mathrm{C}_{\mathrm{i}, \mathrm{fw}-\mathrm{sw}}=\frac{\mathrm{C}_{\mathrm{i}, \mathrm{Cl}}}{\mathrm{C}_{\mathrm{cl}, \mathrm{fwmax}}}\left(\mathrm{C}_{\mathrm{i}, \mathrm{fwmax}}\right)
$$

where, $\mathrm{C}_{\mathrm{i}, \mathrm{Cl}}$ is the $\mathrm{Cl}$ concentration in sample, $\mathrm{C}_{\mathrm{cl}, \text { fwmax }}$ is the highest $\mathrm{Cl}$ concentration of the samples, and $\mathrm{C}_{\mathrm{i}}$, fwmax is the sample with the highest $\mathrm{Cl}$ concentration.

The graphs of major ions versus $\mathrm{Cl}$ represent the chemical composition of the Manglaralto aquifer, indicating concentration and dilution processes. Considering the concentration produced by seawater as a reference, calculated $\mathrm{Ca}, \mathrm{Mg}, \mathrm{Br}$, and $\mathrm{SO}_{4}$ are lower than their concentrations in the samples, while $\mathrm{Na}$ and $\mathrm{K}$ show higher than concentrations. $\mathrm{Calcu}-$ lated sample dilution indicates that there is no dilution process except for the $\mathrm{Cl}$ vs. $\mathrm{Br}$ ratio. In the relation $\mathrm{Cl}$ vs. $\mathrm{HCO}_{3}$, it is observed that $\mathrm{HCO}_{3}$ is kept constant by a chemical equilibrium with calcite. We calculated the saturation with calcite in the PHREEQC program (USGS, United states, version 3.0), for wells P2, P3, and P4 of the August 2018 campaign; the Saturation Index (SI) is zero, and the calculated concentrations of $\mathrm{CaCO}_{3}$ are close to those observed in the field, that is approximately $5 \mathrm{mmol} / \mathrm{L}$ (Figure 6).

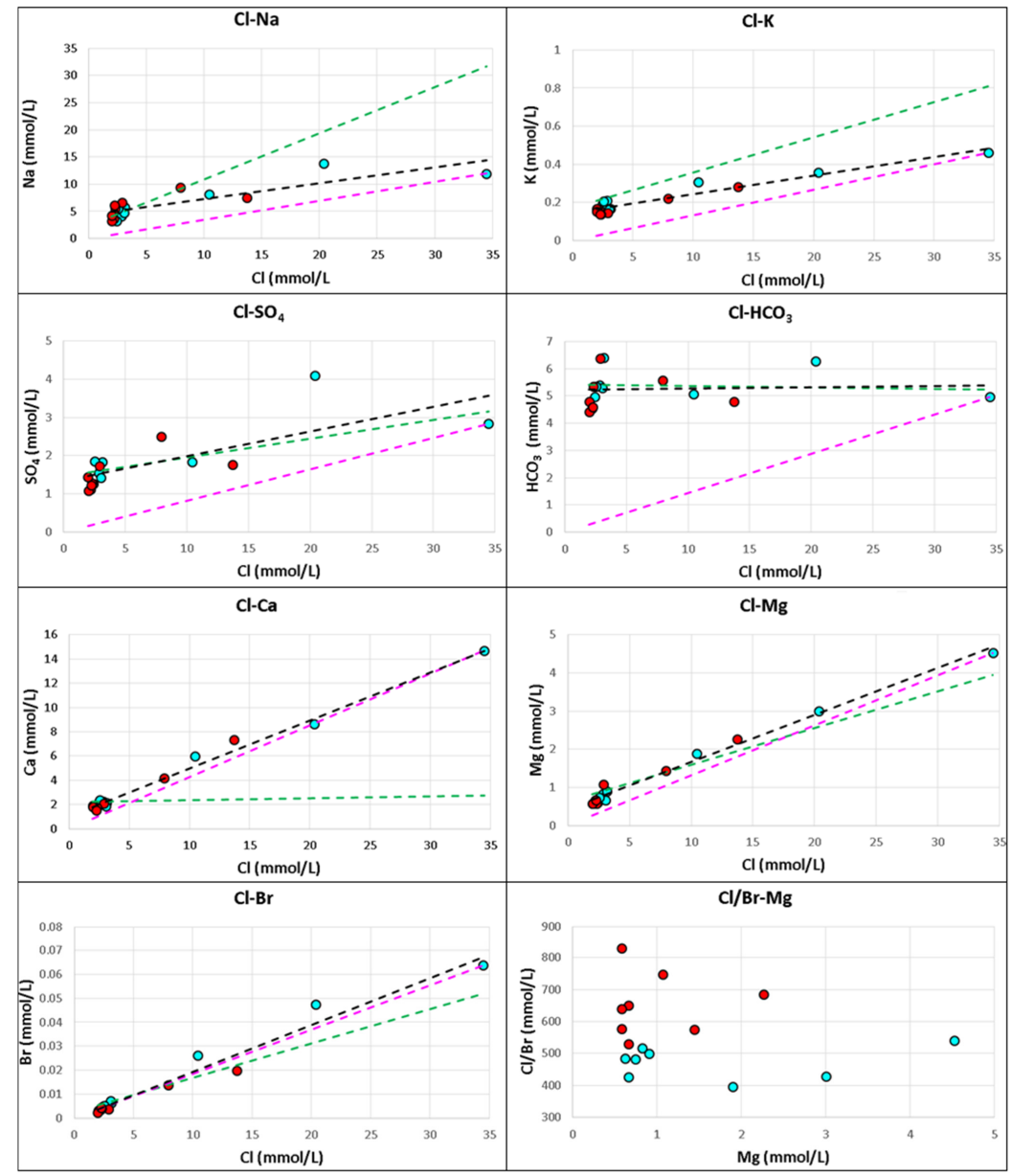

Figure 6. $\mathrm{Cl}$ concentration versus element concentration. The black line indicates the setting of the water samples. The green line represents the theoretical concentration by seawater, and the purple line is the theoretical dilution by rainwater infiltration. 


\subsection{Isotopes}

The reviewed stable isotope data ranges from -2.65 to $-1.73 \%$ in ${ }^{18} \mathrm{O}$ Standard Mean Ocean Water (SMOW) and from -7.6 to $-10.5 \%$ in ${ }^{2} \mathrm{H}$ SMOW (Table 2). When plotted along with the Local Meteoric Line (LMWL) determined by Merino (2014) [40] and the World Weather Line (GMWM) by Craig (1961) [41], the isotopic data indicates that groundwater in the Manglaralto hydrogeological system comes from local rainfall with a low degree of evaporation and short residence time (Figure 7). The data located close to the GMWL is typical of coastal areas and surface waters. The isotopic data for January 2012 are the most evaporated samples and the furthest from the GMWL; in contrast, the campaigns of November 2012, November 2013, and April 2014 fit this line quite well (Figure 7).

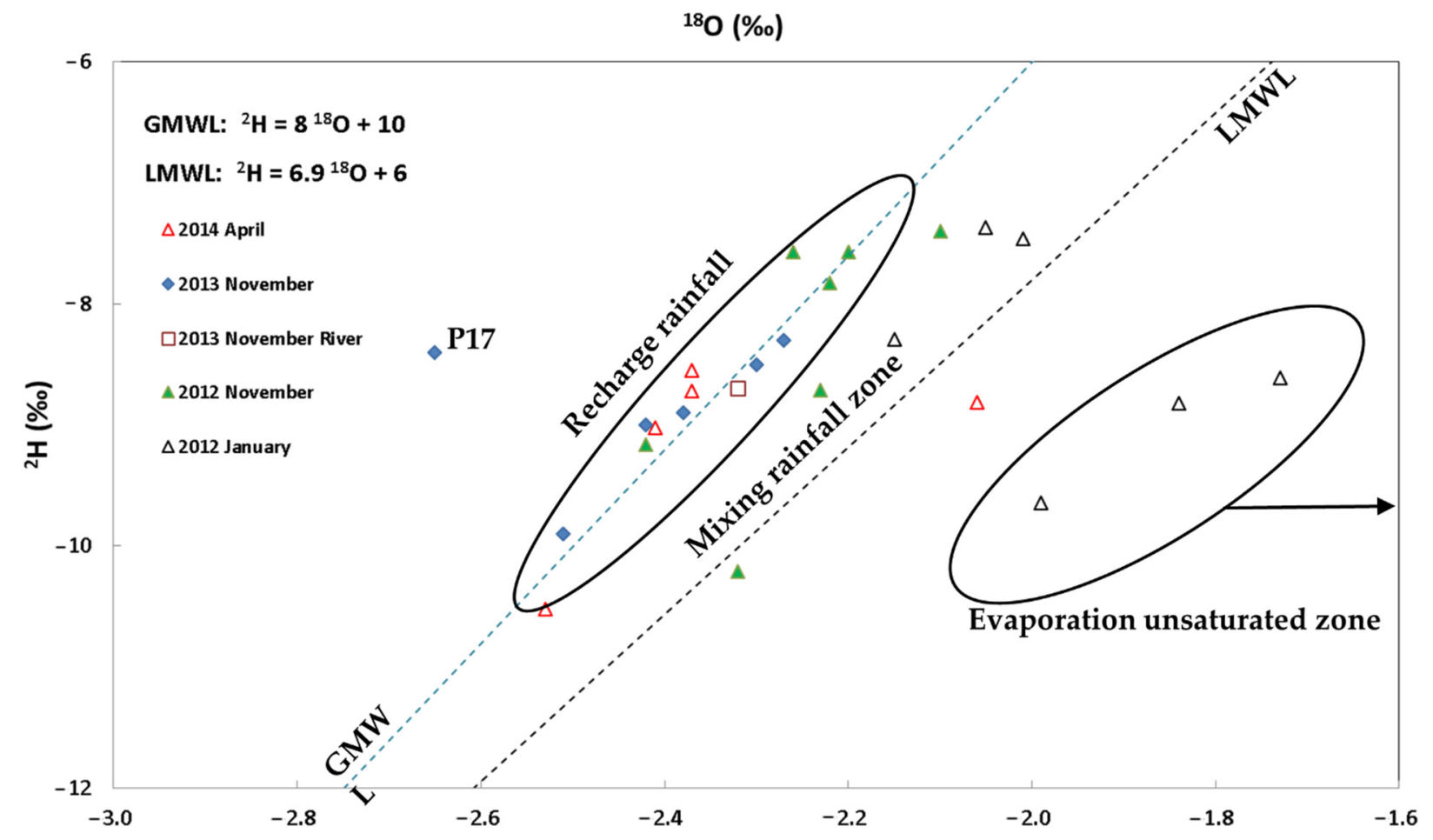

Figure 7. Diagram of the ${ }^{18} \mathrm{O}{ }^{2} \mathrm{H}$ relationship in the surface water and groundwater of the Manglaralto river basin in different sampling campaigns between 2012 and 2014. LMWL: Local Weather Line, GMWL: World Weather Line.

\section{Discussion}

\subsection{Hydrochemistry}

Chemical imprints in groundwater occur due to various factors, which include different rainfall events in the basin, ion exchange, dilution of materials, and anthropic activity [42-45]. In the Manglaralto aquifer, the Piper diagram distinguishes groups of water that depend on rainfall recharge in the area. In the August 2018 campaign, there were two groups: in the first group, the wells located inside the basin have a $\mathrm{Na}-\mathrm{Ca}-\mathrm{CHO}_{3}$ composition (freshwater); the second group corresponds to the wells near the sea, having a calcium Ca-Cl composition (seawater intrusion). In the December 2018 campaign, the first group remains with that composition, while in the second group, the concentration of chloride decreases; thus, salinity decreases due to the mixing of freshwater from the aquifer with seawater at recharge time, as in many coastal aquifers worldwide [46-48].

In both campaigns, the $\mathrm{CI} / \mathrm{Br}$ relationship in the basin corresponds to recharge waters resulting from rainfall in urban coastal areas with pollution influenced by seawater in a semi-arid area [33]. In the wells near the sea, the first campaign corresponds to groundwater with anthropic activity due to septic waste [49]. Moreover, values of fecal coliforms of $40 \mathrm{MPN} / 100 \mathrm{~mL}$ and total coliforms of $150 \mathrm{MPN} / 100 \mathrm{~mL}$ measured in well P3 support this argument. In the second campaign, the infiltration of precipitation that recharges the 
aquifer causes a shift in the classification due to the decrease in the $\mathrm{Cl}^{-}$concentration and the $\mathrm{Cl} / \mathrm{Br}$ ratio, located between both concentrations, producing a mixing process.

In the HFE-D, it indicates that there are wells that would be affected by the seawater intrusion, showing that in the August 2018 campaign, wells P2, P3, and P4 are in the intrusion zone (MixCa-Cl and $\mathrm{Ca}-\mathrm{Cl}$ ), and the wells within the basin are located in a freshwater area with a carbonated mix but with a different cationic concentration $\left(\mathrm{Ca}^{2+}\right.$, $\mathrm{Na}^{+}$). The wells furthest from the sea, $\mathrm{P} 11$ and $\mathrm{P} 12$, are $\mathrm{Ca}-\mathrm{MixHCO}_{3}$, and the remaining wells are $\mathrm{Na}-\mathrm{MixHCO}_{3}$. In the December 2018 campaign, when rainfall has occurred in the basin, only P2 remains in the intrusion zone, observing that the rest of the wells are located in the freshwater area with different states or concentration of $-\mathrm{MixCl},-\mathrm{MixHCO}$ and $-\mathrm{HCO}_{3}$. The process called direct cation exchange occurs in all wells except P2 and P11 due to the infiltration of rainfall into the aquifer producing a refreshing phase, consisting of replacing $\mathrm{Ca}^{2+}$ by $\mathrm{Na}^{+}$in calcium bicarbonate water, a typical process in salinized aquifers that receive freshwater $[35,50,51]$.

The simulation does not reproduce the concentration scenarios from seawater and dilution due to rainwater infiltration. In the first scenario, the $\mathrm{Ca}, \mathrm{Mg}, \mathrm{Br}$, and $\mathrm{SO}_{4}$ concentrations in the aquifer could be due to other contributions from the aforementioned scenarios. The plaster dissolution that emerges in the basin could contribute $\mathrm{CaSO}_{4}$ to the aquifer waters. The acquired high concentrations of $\mathrm{Mg}$ may be due to the dissolution of carbonate rocks. In the case of $\mathrm{Br}$, it would reach these concentrations by dissolving evaporites. The calculated $\mathrm{Na}$ and $\mathrm{K}$, which are above the sample concentrations, could occur by mixing seawater with aquifer water. In the second scenario, the $\mathrm{Cl}$ vs. $\mathrm{Br}$ graph is the only one that reproduces the dilution model (Figure 6).

\subsection{Isotopes}

The stable isotope footprint $\left({ }^{18} \mathrm{O},{ }^{2} \mathrm{H}\right)$ in hydrological systems' waters allows a better knowledge of the origin and processes of evolution exposed. The reinterpreted data for groundwater in the Manglaralto basin vary over time; depending on when in the hydrological year the samples are collected, there are different values for the same well. The samples analyzed in November 2012, November 2013, and April 2014 do not present enrichment in ${ }^{18} \mathrm{O}$ adjusting to the slope of the GMWL, suggesting that the source of recharge would be the coastal rainfall in that area. The sample taken in the Manglaralto river in November 2013 follows this trend concerning the depletion of ${ }^{18} \mathrm{O}$, demonstrating the reduced residence time of groundwater and validating that the gravels, silts, and sands that make up the Holocene aquifer have high hydraulic conductivity; thus the system recharges in short periods. In addition, the P17 that is furthest from the sea shows that it is the lightest result in stable isotopes, indicating that the rainfall in that sector of the basin belongs to a precipitation event different from that of the lower basin and rapid infiltration. Its behavior is something similar to what occurs in karst aquifers in the southern Mediterranean basin in the Teboursouk area (Tunisia), where analyses of a group of waters in that area showed that they conformed to the GMWL, indicating that they do not present evaporation and that the recharge is fast due to the high conductivity of the karst ducts present in the system [52]. However, within this group (including samples from January 2012), wells are located between the GMWL and the LMWL; this would be due to different rainfall events that produce the recharge, causing mixing processes in the aquifer; this commonly occurs in other hydrological systems around the world $[52,53]$. The ${ }^{18} \mathrm{O}$ enrichment of some samples (January 2012 and April 2014) that do not correspond to the meteoric lines indicates that they have undergone evaporation processes in the unsaturated zone [54,55]. During the years when the samples were taken for both isotopes and hydrochemistry, there were no extreme events (e.g., El Niño or La Niña phenomenon) conditioning the determination of recharge zones or a marked variation in the hydrochemistry of water. 


\subsection{Conceptual Model}

A conceptual hydrogeological model of Manglaralto is proposed based on the analysis and interpretation of hydrochemical and isotopic analysis (Figure 7). The chemical analysis of the water in different parts of the aquifer system, especially in the area near the "tapes" allows detecting salt contamination sources. Currently, in another project, a flow and transport model is being configured considering the dykes, based on ancestral knowledge, which influences recharge and saline intrusion. Undoubtedly, this flow and transport model will validate hydrogeochemical dilution-concentration processes in the aquifer. The results (Figure 8) complement and improve the conceptual model presented in Figure 2. In addition to the seasonal effect, there is an influence of artificial recharge due to effects of the dyke, since it stores surface water in the riverbed, leading to a longer residence time of the water and delayed infiltration into the aquifer. The water table and the recharge are variable in time, as indicated by the stable isotopes ${ }^{2} \mathrm{H}$ and ${ }^{18} \mathrm{O}$, occurring exclusively by surface runoff and infiltration of precipitation in the alluvial terraces of gravel and sand that form the unconfined Holocene aquifer. This work proposes that part of the surface runoff infiltrates in the upper and middle basin through cracks and fractures, recharging laterally towards the northeast of the aquifer; in general, circulating water in the aquifer is a mixture produced by different rainfall events. The global flow pattern of the hydrogeological system is from the upper parts of the Chongón-Colonche mountain range (northeast) towards the Pacific Ocean (southwest) [19]. The stable isotopes studied indicate that a fraction of the infiltrating recharge evaporates in the unsaturated zone. Hydrochemical studies show that rainfall recharge freshening the aquifer produces natural cation exchange processes, causing calcium waters to become sodium. In areas close to the sea, the presence of $\mathrm{Ca}-\mathrm{Cl}$ water types shows the presence of seawater intrusion into the interior of the basin, influencing the extraction by pumping to supply the population, decreasing the water table due to overexploitation; the source of concentration within the basin would be produced by the basement saturated with connate seawater. Also, in this area, there would be the presence of underground water contaminated by anthropic activities.

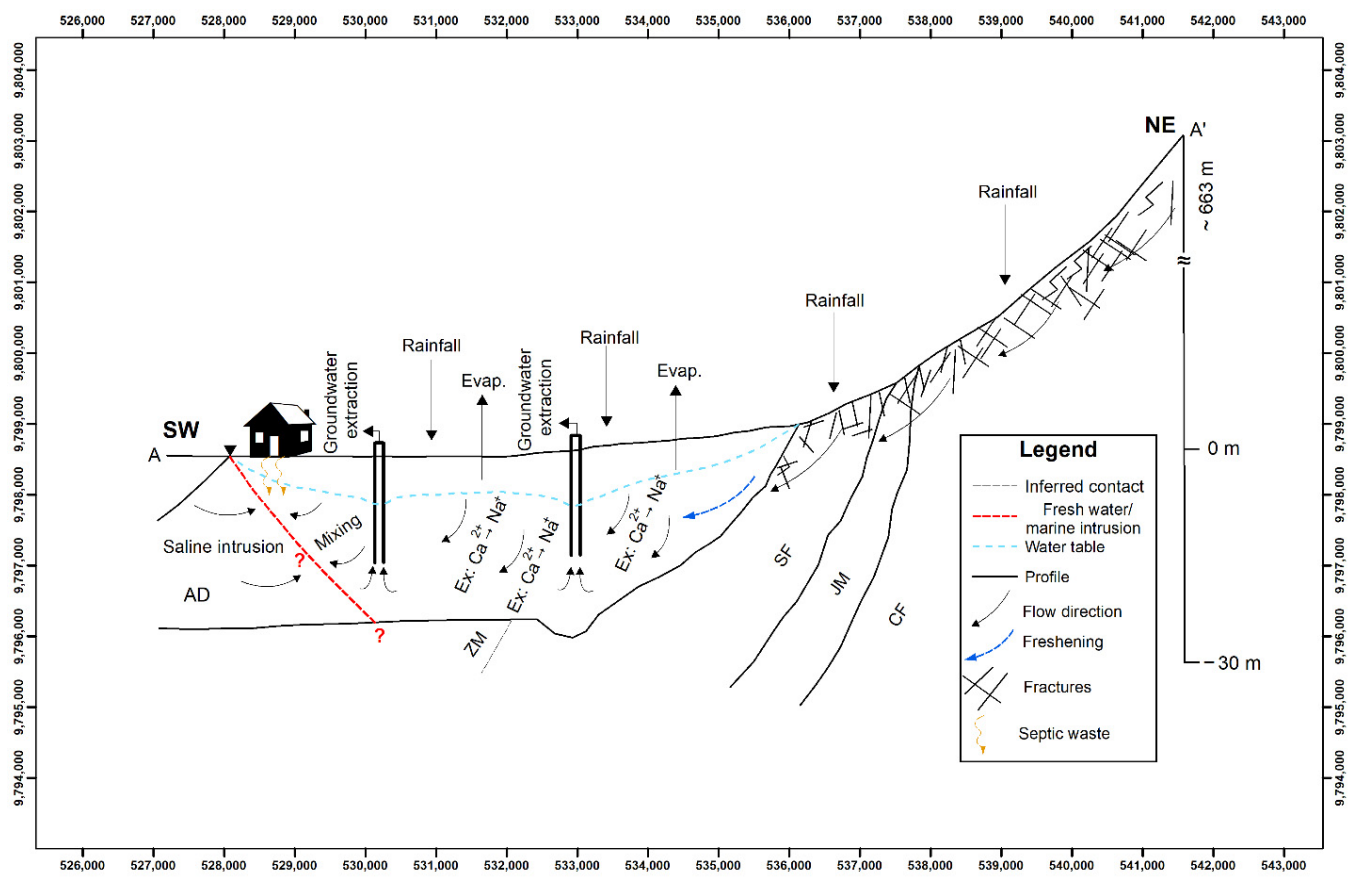

Figure 8. The conceptual hydrogeological model of the Manglaralto river basin based on stable isotope and hydrochemical techniques, showing processes of direct cation exchange, mixing, freshening, recharging, evaporation, and pollution. AD: Alluvial Deposit; ZM: Zapotal member; SF: Socorro formation; JM: Javita member; CF: Cayo formation. 


\section{Conclusions}

The hydrochemical characterization shows that ionic relationships have expanded the knowledge of the hydrogeological system of the Manglaralto basin, regarding the types of water, the origin of salinity, and the presence of seawater intrusion. The waters of this system have a chemical imprint of $\mathrm{Ca}-\mathrm{Na}-\mathrm{Cl}$ and $\mathrm{Ca}-\mathrm{Na}-\mathrm{CHO}_{3} ;$ by mixing processes during rainfall events and cation exchange processes $\left(\mathrm{Ca}^{2+}\right.$ to $\left.\mathrm{Na}^{+}\right)$, the aquifer water is refreshed with recent water from the recharge in the basin. The anthropic activity reflected in the wells near the sea would be caused by the wastewater from the urban area that infiltrates into the intrusion wedge that enters the continent. $\mathrm{Ca}-\mathrm{Cl}^{\prime}$ s chemical footprint in the wells near the coast indicates the presence of seawater intrusion in the basin, mainly in dry seasons, salinizing groundwater in these areas aggravated by pumping extractions.

Characterization using stable isotopic techniques indicates that the types of waters present in the basin are due to different rainfall events. In one of these types, the water infiltrates in short periods from the surface runoff of the Manglaralto river, according to the aquifer's high hydraulic permeability. In contrast, in another type, there is a mixture of different rainfall events, therefore there are waters with different degrees of evaporation in the unsaturated zone.

The conceptual model allows expanding the knowledge of the hydrological functioning in the Manglaralto basin, which establishes that rainfall is the main parameter concerning the types of water, as well as that it is the only recharge source with a short residence time in the aquifer; marine intrusion would be present and mixing with wastewater from human activity.

The chemical and isotopic studies carried out in the Manglaralto basin contribute to the knowledge of the behavior of coastal aquifers' behavior where hydrochemical characteristics are conditioned by sources other than seawater. The concentration of chloride in the inland wells comes from the aquifer basement, which is saturated with connate seawater, while in the wells near the sea, it is related to both seawater intrusion and the basement. These interpretations are deduced from the analysis of the concentration curves by seawater and dilution curves by infiltration of rainwater. With the knowledge gained in this work, it concludes that for the correct management of the aquifer, actions should be taken to protect recharge areas in the basin (river, alluvial terraces, and higher areas of the Chongón-Colonche mountain range). Studies are required in the basin's urban area to treat wastewater and dispense with septic tanks in homes.

Author Contributions: Conceptualization, P.C.-M., F.J.M., F.M.-C., and J.H.; methodology, F.J.M., P.C.-M., F.M.-C., F.J.E., and J.H..; software, J.H., F.J.E., J.S., and H.A.; validation, P.C.-M., F.J.M., and J.H.; formal analysis, P.C.-M., F.J.M., F.M.-C., J.S., and H.A.; investigation, P.C.-M., F.J.M., F.M.-C., and J.H.; resources, P.C.-M. and F.J.M.; data curation, P.C.-M., F.J.M., and J.S.; writing—original draft preparation, F.J.M., J.S., and H.A.; writing-review and editing, P.C.-M., F.J.M., F.M.-C., J.S., and H.A.; visualization, F.J.M. and J.S.; supervision, P.C.-M., F.J.M., and F.M.-C.; project administration, P.C.-M., F.J.M., and F.M.-C.; funding acquisition, P.C.-M. and F.J.M. All authors have read and agreed to the published version of the manuscript.

Funding: The UPSE funded this project: "Geophysical and hydrochemical characterization of the Manglaralto aquifer for the sustainability of the water resource". CODE: 91870000.0000 .382444$. The ESPOL Social Link Project funded this research: "Resilience in water management, in the face of COVID-19, Manglaralto". CODE: PG03-PY20-03 and the IAEA Project: "Improvement of coastal aquifers' management by studying the recharge rate of the alluvial aquifer of the Manglaralto river basin". CODE: ECU/7/005.

Institutional Review Board Statement: Not applicable.

Informed Consent Statement: Not applicable.

Data Availability Statement: Not applicable.

Acknowledgments: The authors want to thank the members of the JAAPMAN Water Board, especially the president Ms Rocío Muñoz, for the ESPOL Project: "Register of geological and mining 
heritage and its incidence in the defence and preservation of geodiversity in Ecuador" CODE: CIPAT-01-2018, and the UPSE projects: "Geophysical and hydrochemical characterization of the Manglaralto aquifer for the sustainability of the water resource" CODE: 91870000.0000 .382444 and "Coastal network of environmental isotopes for analysis of hydrographic basins" CODE: INCYTPNF-2019-G42-98 for the preparation of this work, also to JAAPMAN for the logistics provided in field trips. The hydrogeological characteristics of the aquifer were obtained by the Research and Projects Center Applied to Earth Sciences (CIPAT-ESPOL by its acronym in Spanish) of the ESPOL Polytechnic University (ESPOL by its acronym in Spanish) within the framework of the projects of the International Atomic Energy Agency (IAEA): ECU/8/026: “Characterization of Coastal Aquifers in the Santa Elena Peninsula and RLA/8/041: "Application of Isotopic Tools for Integrated Management of Coastal Aquifers". We thank the young CIPAT researchers: Boris Apolo, Ma. Carolina Loor, Ximena Quiñonez, Lady Bravo, and all those who collaborated in the field campaigns to collect data.

Conflicts of Interest: The authors declare no conflict of interest.

\section{References}

1. Bahir, M.; Chkir, N.; Trabelsi, R.; Friha, H.A.; Zouari, K.; Chamchati, H. Hydro-geochemical behaviour of two coastal aquifers under severe climatic and human constraints: Comparative study between Essaouira basin in Morocco and Jeffara basin in Tunisia. Int. J. Hydrol. Sci. Technol 2012, 2, 75-100. [CrossRef]

2. Maurya, P.; Kumari, R.; Mukherjee, S. Hydrochemistry in integration with stable isotopes $\left(\delta^{18} \mathrm{O}\right.$ and $\left.\delta \mathrm{D}\right)$ to assess seawater intrusion in coastal aquifers of Kachchh district, Gujarat, India. J. Geochem. Explor. 2019, 196, 42-56. [CrossRef]

3. Collet, I.; Engelbert, A. Coastal Regions: People Living Along the Coastline, Integration of NUTS 2010 and Latest Population Grid. 2013. Available online: http:/ / ec.europa.eu/eurostat/web/products-statistics-in-focus/-/KS-SF-13-030 (accessed on 3 September 2017).

4. Small, C.; Nicholls, R.J. A global analysis of human settlement in coastal zones. J. Coast. Res. 2003, 19, 584-599.

5. Bear, J.; Cheng, A.H.-D.; Sorek, S.; Ouazar, D.; Herrera, I. Seawater intrusion in coastal aquifers: Concepts, methods and practices. In Theory and Applications of Transport in Porous Media; Springer: Heidelberg, Germany, 1999; p. 625.

6. Slim, D.; Loeza, C.; Munguía, N.; Peralta, J.; Velazquez, L. Sustainability strategies for coastal aquifers: A case study of the Hermosillo Coast aquifer. J. Clean. Prod. 2017, 195, 1170-1182.

7. Oude Essink, G.H.P. Improving fresh groundwater supply-Problems and solutions. Ocean. Coast. Manag. 2001, 44, 429-449. [CrossRef]

8. Park, S.-C.; Yun, S.-T.; Chae, G.-T.; Yoo, I.-S.; Shin, K.-S.; Heo, C.-H.; Lee, S.-K. Regional hydrochemical study on salinization of coastal aquifers, western coastal area of South Korea. J. Hydrol. 2005, 313, 182-194. [CrossRef]

9. Custodio, E. Groundwater quantity and quality changes related to land and water management around urban areas: Blessings and misfortunes. In Proceedings of the 27th IAH Congress on Groundwater in the Urban Environment: Problems, Processes and Management; Chilton, J., Ed.; Balkema: Rotterdam, The Netherlands, 1997; pp. 11-22.

10. Houéménou, H.; Tweed, S.; Dobigny, G.; Mama, D.; Alassane, A.; Silmer, R.; Babic, M.; Ruy, S.; Chaigneau, A.; Gauthier, P.; et al. Degradation of groundwater quality in expanding cities in West Africa. A case study of the unregulated shallow aquifer in Cotonou. J. Hydrol. 2020, 582. [CrossRef]

11. Dhanasekarapandian, M.; Chandran, S.; Devi, D.S.; Kumar, V. Spatial and temporal variation of groundwater quality and its suitability for irrigation and drinking purpose using GIS and WQI in an urban fringe. J. Afr. Earth Sci. 2016, 124, 270-288. [CrossRef]

12. Herrera-Franco, G.; Carrión-Mero, P.; Alvarado, N.; Morante-Carballo, F.; Maldonado, A.; Caldevilla, P.; Berrezueta, E. Geosites and Georesources to Foster Geotourism in Communities: Case Study of the Santa Elena Peninsula Geopark Project in Ecuador. Sustainability 2021, 12, 4484. [CrossRef]

13. Mora, A.; Mahlknecht, J.; Ledesma-Ruiz, R.; Sanford, W.E.; Lesser, L.E. Dynamics of major and trace elements during seawater intrusion in a coastal sedimentary aquifer impacted by anthropogenic activities. J. Contam. Hydrol. 2020, 232. [CrossRef]

14. Peña, H.; Suzuki, O.; Rauert, W. Isotope Hydrology Investigations in Latin America; Organismo Internacional de Energía Atómica, Estudio de Hidrología Isotópica en el Área del Salar de Llamara, Desierto de Atacama: Chile, Vienna, 1989; Volume 502, p. 113.

15. El Universo. Available online: www.eluniverso.com (accessed on 12 April 2019).

16. Núñez del Arco, E. Geología del Ecuador, 1st ed.; Escuela Superior Politécnica del Litoral: Guayaquil, Ecuador, $2003 ;$ pp. $42-49$.

17. Machiels, L.; Morante, F.; Snellings, R.; Calvo, B.; Canoira, L.; Paredes, C.; Elsen, J. Zeolite mineralogy of the Cayo formation in Guayaquil, Ecuador. Appl. Clay Sci. 2008, 42, 180-188.

18. Machiels, L.; Garcés, D.; Snellings, R.; Vilema, W.; Morante, F.; Paredes, C.; Elsen, J. Zeolite occurrence and genesis in the Late-Cretaceous Cayo arc of Coastal Ecuador: Evidence for zeolite formation in cooling marine pyroclastic flow deposits. Appl. Clay Sci. 2014, 87, 108-119. [CrossRef]

19. Morante, F.; Montalván, F.J.; Carrión, P.; Herrera, G.; Heredia, J.; Elorza, F.J.; Pilco, D.; Solórzano, J. Hydrochemical and geological correlation to establish the groundwater salinity of the coastal aquifer of the Manglaralto River basin, Ecuador. WIT Trans. Ecol. Environ. 2019, 229, 139-149. 
20. Campoverde, J.; Fajardo, I. Contribución de la Geología Aplicada Para la Mejora en el Diseño de un Dique en la Subcuenca del rio Manglaralto, Provincia de Santa Elena; Escuela Superior Politécnica del Litoral (ESPOL): Guayaquil, Ecuador, 2018.

21. Arévalo, M. Propuesta de Diseño de Construcción, Acondicionamiento de un pozo de Agua y su Incidencia en la Vulnerabilidad del Acuífero Costero en Manglaralto. Master's Thesis, Escuela Superior Politécnica del Litoral (ESPOL), Guayaquil, Ecuador, 2017.

22. Herrera, G. Estudio para un Modelo de Gestión de un Acuífero Costero, mediante Metodologías Participativas y Análisis Geoestadístico en el marco del Desarrollo Local. Ph.D. Thesis, Universidad Politécnica de Madrid (UPM), Madrid, España, 2015.

23. Herrera-Franco, G.; Alvarado-Macancela, N.; Gavín-Quinchuela, T.; Carrión-Mero, P. Participatory socio-ecological system: Manglaralto-Santa Elena, Ecuador. Geol. Ecol. Landsc. 2018, 2, 303-310. [CrossRef]

24. Instituto Nacional de Estadísticas y Censos (INEC). VII Censo de Población y VI de Vivienda: Sistema Integrado de Consultas. Available online: http:/ / redatam.inec.gob.ec/ (accessed on 2 October 2020).

25. Carballo, F.M.; Brito, L.M.; Mero, P.C.; Aguilar, M.A.; Ramírez, J.T. Urban wastewater treatment through a system of green filters in the Montañita commune, Santa elena, Ecuador. WIT Trans. Ecol. Environ. 2019, 239, 233-249.

26. Franco, G.H.; Quinchuela, T.G.; Macancela, N.A.; Mero, P.C. Participative analysis of socio-ecological dynamics and interactions. A case study of the Manglaralto coastal aquifer, Santa Elena-Ecuador. Malays. J. Sustain. Agric. 2017, 1, 19-22. [CrossRef]

27. Herrera-Franco, G.; Carrión-Mero, P.; Aguilar-Aguilar, M.; Morante-Carballo, F.; Jaya-Montalvo, M.; Morillo-Balsera, M. Groundwater Resilience Assessment in a Communal Coastal Aquifer System. The Case of Manglaralto in Santa Elena, Ecuador. Sustainability 2020, 12, 8290. [CrossRef]

28. Carrión, P.; Herrera, G.; Briones, J.; Sánchez, C.; Limón, J. Practical adaptations of ancestral knowledge for groundwater artificial recharge management of Manglaralto coastal aquifer, Ecuador. WIT Trans. Ecol. Environ. 2018, 217, 375-386.

29. Herrera Franco, G.; Carrión Mero, P.; Briones Bitar, J. Management practices for a sustainable community and its impact on development, Manglaralto-Santa Elena, Ecuador. In Proceedings of the 17th LACCEI International Multi-Conference for Engineering, Education, and Technology, Montego Bay, Jamaica, 24-26 July 2019; pp. 24-26.

30. Macneill, M. IAEA Helps Parched Santa Elena Find Water; IAEA Bulletin 53-1 (Online): Vienna, Austria, 2011; Volume 53, pp. 12-13.

31. Piper, A.M. A graphic procedure in the geochemical interpretation of water-analyses. Eos Trans. Am. Geophys. Union 1944, 25, 914-928. [CrossRef]

32. Vazquez-Suñé, E.; Serrano-Juan, A. Easy_Quim v. 5.0. Available online: https://h2ogeo.upc.edu/es/software-hidrologiasubterrania/11-software-hidrologia-subterrania/42-easy-quim (accessed on 9 November 2019).

33. Alcalá, F.J.; Custodio, E. Using the $\mathrm{Cl} / \mathrm{Br}$ ratio as a tracer to identify the origin of salinity in aquifers in Spain and Portugal. J. Hydrol. 2008, 359, 189-207. [CrossRef]

34. Giménez-Forcada, E. Dynamic of sea water interface using hydrochemical facies evolution diagram. Ground Water 2010, 48, 212-216. [CrossRef] [PubMed]

35. Giménez-Forcada, E. Space/time development of seawater intrusion: A study case in Vinaroz coastal plain (Eastern Spain) using HFE-Diagram, and spatial distribution of hydrochemical facies. J. Hydrol. 2014, 517, 617-627. [CrossRef]

36. Giménez-Forcada, E. Use of the Hydrochemical Facies Diagram (HFE-D) for the evaluation of salinization by seawater intrusion in the coastal Oropesa Plain: Comparative analysis with the coastal Vinaroz Plain, Spain. HydroResearch 2019, 2, 76-84. [CrossRef]

37. Monnin, C.; Tamborski, J.; Bejannin, S.; Souhaut, M.; Roques, M.; Olivier, P.; van Beek, P. Freshening of a Coastal Karst Aquifer Revealed by the Temporal Changes in a Spring Water Composition (La Palme, Southern France). Hydrology 2019, 6, 45. [CrossRef]

38. Young, C.; Martin, J.B.; Branyon, J.; Pain, A.; Valle-Levinson, A.; Mariño-Tapia, I.; Vieyra, M.R. Effects of short-term variations in sea level on dissolved oxygen in a coastal karst aquifer, Quintana Roo, Mexico. Limnol. Oceanogr. 2017, 63, 352-362. [CrossRef]

39. Appelo, C.A.J.; Postma, D. Geochemistry, Groundwater, and Pollution; A.A. Balkema: Amsterdam, The Netherlands, 2005.

40. Merino, E. Evaluación de la intrusión salina en un acuífero costero y el impacto al suministro de agua potable en Manglaralto provincia de Santa Elena. Bachelor's Thesis, Escuela Superior Politécnica del Litoral (ESPOL), Guayaquil, Ecuador, 2014.

41. Craig, H. Standard for reporting concentrations of deuterium and oxygen-18 in natural waters. Science 1961, 133, 1833-1834. [CrossRef] [PubMed]

42. Appelo, C.A.J.; Postma, D. Geochemistry, Groundwater and Pollution, 2nd ed.; CRC Press: London, UK, 2004. [CrossRef]

43. Karanth, K. Ground Water Assessment: Development and Management; Tata McGraw-Hill Education: New York, NY, USA, 1987.

44. Kim, Y.; Lee, K.S.; Koh, D.C.; Lee, D.H.; Lee, S.G.; Park, W.B.; Koh, G.W.; Woo, N.C. Hydrogeochemical and isotopic evidence of groundwater salinization in a coastal aquifer: A case study in Jeju volcanic island, Korea. J. Hydrol. 2003, 270, 282-294. [CrossRef]

45. Ma, R.; Sun, Z.; Hu, Y.; Chang, Q.; Wang, S.; Xing, W.; Ge, M. Hydrological connectivity from glaciers to rivers in the Qinghai-Tibet Plateau: Roles of suprapermafrost and subpermafrost groundwater. Hydrol. Earth Syst. Sci. 2017, 21, 4803-4823. [CrossRef]

46. Liu, S.; Tang, Z.; Gao, M.; Hou, G. Evolutionary process of saline-water intrusion in Holocene and Late Pleistocene groundwater in southern Laizhou Bay. Sci. Total Environ. 2017, 607-608, 586-599. [CrossRef]

47. Mohanty, A.K.; Rao, V.V.S.G. Hydrogeochemical, seawater intrusion and oxygen isotope studies on a coastal region in the Puri District of Odisha, India. Catena 2019, 172, 558-571. [CrossRef]

48. De Montety, V.; Radakovitch, O.; Vallet-Coulomb, C.; Blavoux, B.; Hermitte, D.; Valles, V. Origin of groundwater salinity and hydrogeochemical processes in a confined coastal aquifer: Case of the Rhône delta (Southern France). Appl. Geochem. 2008, 23, 2337-2349. [CrossRef] 
49. Gomes, O.V.O.; Marques, E.D.; Kütter, V.T.; Aires, J.R.; Travi, Y.; Silva-Filho, E.V. Origin of salinity and hydrogeochemical features of porous aquifers from northeastern Guanabara Bay, Rio de Janeiro, SE-Brazil. J. Hydrol. Reg. Stud. 2019, 22. [CrossRef]

50. Appelo, C.A.J.; Geirnaert, W. Processes accompanying the intrusion of salt water. Geol. Appl. e Idrogeol. 1983, 18, 29-40.

51. Han, D.; Post, V.E.A.; Song, X. Groundwater salinization processes and reversibility of seawater intrusion in coastal carbonate aquifers. J. Hydrol. 2015, 531, 1067-1080. [CrossRef]

52. Ayadi, Y.; Mokadem, N.; Besser, H.; Khelifi, F.; Harabi, S.; Hamad, A.; Boyce, A.; Laouar, R.; Hamed, Y. Hydrochemistry and stable isotopes $(\delta 18 \mathrm{O}$ and $\delta 2 \mathrm{H})$ tools applied to the study of karst aquifers in southern mediterranean basin (Teboursouk area, NW Tunisia). J. African Earth Sci. 2018, 137, 208-217. [CrossRef]

53. Joshi, S.K.; Rai, S.P.; Sinha, R.; Gupta, S.; Densmore, A.L.; Rawat, Y.S.; Shekhar, S. Tracing groundwater recharge sources in the northwestern Indian alluvial aquifer using water isotopes $(\delta 18 \mathrm{O}, \delta 2 \mathrm{H}$ and $3 \mathrm{H})$. J. Hydrol. 2018, 559, 835-847. [CrossRef]

54. Gopinath, S.; Srinivasamoorthy, K.; Saravanan, K.; Prakash, R. Tracing groundwater salinization using geochemical and isotopic signature in Southeastern coastal Tamilnadu, India. Chemosphere 2019, 236. [CrossRef] [PubMed]

55. He, Z.; Ma, C.; Zhou, A.; Qi, H.; Liu, C.; Cai, H.; Zhu, H. Using hydrochemical and stable isotopic $(\delta 2 \mathrm{H}, \delta 18 \mathrm{O}, \delta 11 \mathrm{~B}$, and $\delta 37 \mathrm{Cl})$ data to understand groundwater evolution in an unconsolidated aquifer system in the southern coastal area of Laizhou Bay, China. Appl. Geochem. 2018, 90, 129-141. [CrossRef] 